だから私はタピオカミルクティーに さよならしなければならない

Kotomi LI (李琴峰: Chinese-Japanese Translator)

(日本) 日中二言語作家、翻訳家。小説『独り舞』(原題「独舞」) にて第60回群像新人文学賞優秀作を受賞。2019年、小説『五 つ数えればニ日月が』で、第161回芥川龍之介賞、第41回野間 文芸新人賞候補。

\section{The Reason Why I Should Part Ways with Tapioca Milk Tea}

When meeting with those from overseas countries, people tend to form a perspective on them based on their nationalities, thereby ignoring individual distinctiveness. As for me, since I am from Taiwan, people often assume my personal characteristics, from my taste in food to my core values, based on their idea of what constitutes a "standard or stereotypical" Taiwanese person. Some even become suspicious of me if $I$ act in a way that is contrary to their expectations, and this makes me uncomfortable. As can be seen from the history of Yonaguni, borders are sometimes arbitrary and highly unstable, and thus, it is unreasonable to try to understand people based on them. In light of this and based on my own experience, in this essay I suggest that people should see each other not according to national categories, but as individuals.

Keywords Tapioca(タピオカ), Borderline(国境線), Yonaguni(与邦国), Taiwan(台湾)

タピオカブームなるものが来ているよう である(というかそろそろ衰退か？)。

周知の通り、タピオカドリンクというの は台湾発の飲料だ。台湾で爆発的に流行った
のち、欧米にも進出した。二○一五年に初め てアメリカへ旅行に行き、街角で賑わう台 湾発のドリンクスタンドを目にした時はか なりびっくりした。距離が近い中国や香港 ならまだしも、遠い海を越えてアメリカに まで店舗を展開したのだから驚きものであ る。逆に距離の近い日本では、当時はまだ ほとんどその類のドリンクスタンドが見え なかった。

ところがとうとう、日本にもタピオカ ブームが来ているのだ。

このブームの到来を喜ぶ台湾出身者や台 湾関係者は大勢いるらしい。「タピオカドリ ンクは台湾の光だ」とはしゃぐ人もいるし、 台湾の若者が台湾の食文化を日本で広めるた めにドリンクスタンドをオープンしたとこ ろ成功を収めた、なんていう美談も時々目 にする。しかし、街に次々と展開される夕 ピオカドリンクの店舗、その店舗に並ぶ長 蛇の列、「タピ活」アピリスト」「タピる」の ような流行語、タピオカを取り上げるテレ ビのワイドショーやネットのトレンド、タ ピオカのインスタ映えの写真、タピオカラ ンドという謎の施設、しまいにはタピオカ オムレツにタピオカ麻婆にタピオカ筑前 煮、そしてタピオカのアクセサリーからス トラップからテンガカップまで……とかく タピオカでゲシュタルト崩壊を起こし眩暈 がしてしまいそうなこの社会現象を、私は 常に冷めた目で見ている。

何を隠そう、私はタピオカが嫌いなの だ。

私にとってタピオカの存在は、子供時代 からの謎である。

そんなもちもちしていて噛んでも噛んで も噛み切れないものを、一体なんで人々は 
飲み物の中に入れて好んで飲んでいる(食べ ている?）のだろうか。人々は喉が渴いたか らこそドリンクを飲むのであって、飲むか らにはごくごく飲みたいのであって、その ドリンクの中にごくごく飲むことを邪魔し てくる物体を入れるというのは、一体どう いう了見だろうか。

え一、台湾人のくせに！と、これまで何 度言われたことか。

タピオカだけじやない。パイナップル ケーキもマンゴーも蚵㦿㨵も、サッマイモ ご飯も面神湯も杏仁茶も、台湾料理とされて いるものの多くを、私は嫌いなのである。 というより、そもそも食べ物として認識し ていないのである。夜市(夜市自体は好きだ) を漫ろ歩きしていても、これらの料理は自 動的に目のフィルターに濾過され、脳の認 識範囲に入らないのである。

この通り私は偏食者である。辛いものも 苦いものも酸っぱいものも、魚介類も生野 菜も味覚的には受け付けないので、食事会や 飲み会では散々苦労してきた。「これ、辛く ないよ?」と言われて食べたものが辛くて舌 が火傷しそうになったり、「全然酸っぱくな いから」と言われて飲んだものが酸っぱくて 㚘頁っぺたが萎んで抜け落ちそうになった り、これまでの経験から人間不信になって もおかしくないレベルである。どうやら私 にとっての「辛い」酸っぱい」の境界線は他 人とはかなり違うようだ。他人が引いた境 界線への盲信は禁物である。

日本に来てから、自分は辛いもの／苦い もの/酸っぱいもの/海鮮が食べられない と表明すると、往々にして「台湾ではあまり 辛いもの／苦いもの／酸っぱいもの／海鮮 を食べないの? 」と言わ机る。十回で九・五
回は言わ机る耳にタコができそうであ る。その度に心の中で叫んでいる。「台湾で は食べないのではなくて、私が食べないの だ!扮願いだから、私を『台湾人』という力 テゴリーとしてではなく、個人として見 て!」と。

もち万ん、こう見えても小心者だからこ れはあくまで心の叫びであり、よっぽど仲 の良い友人でもなければそうは言いづらい のである。しかしそうしたマイクロ・アグ レッション(悪意なき、小さな差別)を受け る度に、溜息を吐かずにはいられない。た とえ台湾から日本に渡り、物理的な「国境線」 を越えたとしても、人々の心の中にある無 形な「国境線」までは越えられていないよう だ。

私は時々不思議に思う。どうやら人々が 想像している「国境線」なるものはとても厳 然としていて、話す言葉から住む家の様 式、慣れている交通手段から物事に対する考 え方、政治観価值観そして食べるものまで も、その線によって全てが決まるようであ る。臭豆腐を食べない台湾人だって、納豆を 食べない日本人だっているのだから、少し 考えてみればそんなことはあり得ないと分 かるはずなのに、人々は国境線の向こうに いる他者と対峙するといとも簡単に個体へ の想像力を失い、ついその線で全てを解釈 しようとしがちである。

歴史を紐解けば、国境線というものはふ とした拍子にいとも簡単に移り変わるもの であることが分かる。それは決して固定し たものではなく、常に変動する可能性を内 包していて、場合によっては曖昧性すら带 びるものである。最近小説の取材で、与那国 という茜国境の島に行ってきたが、この島 
はまさに好例である。

十六世紀以前に与那国は絶海の孤島で、 海を通して色々な島と緩やかな交流を持っ ていたものの、どこの国にも隷属しなかっ た。一五一○年に琉球の侵攻により、与那国 は初めて琉球王国の版図に入り、一六○九年 の薩摩藩による琉球侵攻以降、薩摩に対して 納税せざるを得なくなった。殺戴による口 減らしを曼延らせた人頭税の施行もおよそ この時期である。一八七○年代の琉球処分に よって与那国は大日本帝国の一部となった が、日清戦争後に台湾も大日本帝国の領土に 入り、一一一キロしか離れていないこの二 つの島は盛んな人的・物的交流を開始した。 与那国の人久は、進学先、就職先、食料や生 活物資を帝国の内地よりも、至近の台湾島に 求めたのである。しかしいざ敗戦してみる と、大海原にいきなり国境線が引かれ、そ れまで与那国の人々の生活を支えていた台湾 との海上貿易は一夕にして違法な密貿易と なった。沖縄と共にアメリカの占領下と なった与那国は十分な物資が与えられず、台 湾との「密貿易」を続けるしかなかった。与 那国の歴史は、その時々の権力者の方針や 国々の勢力によって決められた国境線に翻弄 される歴史、と言い換えてもいい。この研 究論集のタイトルは『跨境』なのだが、島民 からすれば、跨境も何も、勝手に境界線を引 かれているだけなのに、ともどかしい気持 ちになるのではないかと想像する。

跨境も何も、勝手に境界線を引かれてい るだけなのに一ここの地球という星、見渡 せ女海原、荒漠たる蒼穹、そこに人類が勝手 に引いた国境線がまるで子供の落書きのよ うに思われる人は、私だけだろうか。ただ の子供の落書きなのに、私達は無力にも翻弄
され、規定され、場合によっては食べるも のにまで先入観を持たれる。「○○人」であ る以前に、私達は独立した、一個の人間とし てこの世界に生まれたはずなのに。国境線 だけではない。人種、性別、性的指向の境界 線についても、同じことが言えると思う。 そうした属性による規定から解放され、真 に一個の人間として互いに向き合えるよう になるその時こそ、「跨境」は本当の意味で 達成され得るのではないだろうか。

だから私はタピオカミルクティーにさよ ならしなければならない。パイナップル ケーキにもマンゴーのかき氷にもだ。台湾 人だからでも、台湾人離机しているからで もない。私は独自の好悪、独自の価值観と世 界観を持っている、李琴峰という一個の人間 だからである。 